\section{ECONOMICS}

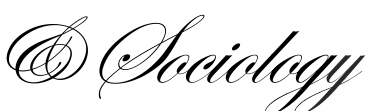

\title{
MULTI-CRITERIA ASSESSMENT OF SOCIOECONOMIC SYSTEMS' CONDITIONS BASED ON HIERARCHICALLY STRUCTURED INDICATOR SYSTEMS
}

\section{Romualdas Ginevičius \\ Bialystok University of Technology, \\ Bialystok, Poland \\ E-mail: \\ romualdas.ginevicius@,vgtu.lt \\ ORCID 0000-0003-2067-4398}

Received: January, 2020

1st Revision: May, 2020

Accepted: December, 2020

DOI: $10.14254 / 2071-$

789X.2020/13-4/16

JEL Classification: C61, $\mathrm{O} 12, \mathrm{O} 21$

\begin{abstract}
The adequacy of multi-criteria assessment largely depends on how comprehensively an indicator system reflects a phenomenon under consideration. If the number of indicators is large, experts cannot adequately evaluate the indicator weights. As a result, the scope of calculations increases significantly, but the accuracy drops. This problem can be solved by forming a hierarchically structured indicator system. Multi-criteria assessment of such systems is started from the lowest hierarchical level where the values of the related indicator groups are estimated, and then they turn into the indices of a higher hierarchical level. Same procedure is repeated until a value representing the condition of a phenomenon under consideration is obtained.
\end{abstract}

Keywords: multi-criteria assessment methods, hierarchically structured indicator systems

\section{Introduction}

The objects of social science research are complex phenomena or processes that are inherently socioeconomic systems (SESs). Literature analysis shows that the research into such systems usually involves either analysis of the impact of influential determinants or quantitative assessment of a system's condition. In the first case, due to its versatility, simplicity and opportunities provided, correlation-regression analysis is employed (Chowlhury \& Squire, 2006; Babu \& Datta, 2015; Boggia et al., 2014; Bilan et al., 2019). In the second case, the methods of multi-criteria assessment are invoked due to their flexibility and consideration of several possible alternatives (Gedvilaitè, 2019; Oželienè, 2019, Volkov, 2018). The key difference between the two abovementioned methods is that correlation-regression analysis is possible only when the condition of a phenomenon or process under consideration (PPC) is known. The main purpose of the analysis is to assess the impact of influential determinants on a PPCm either considering, or disregarding the interrelationship among the determinants. A pairwise correlation-regression is employed when the interrelationship among the determinants is considered, while polynomial correlation-regression is conducted when this interrelationship is disregarded. Multi-criteria assessment methods are applied when the condition of a PPC is not known and needs to be assessed. The purpose of this analysis is to prioritise the options considered (Molly, 2018; Strezov et al., 2017). 
As fundamental instruments of the research into SESs, correlation-regression and multicriteria assessment methods do not compete, but rather complement each other, thus forming a comprehensive system of complex research. The choice of factors influencing SESs development depends on aim and objectives of research, scale of the SESs, so, they can include performance indicators or its prerequisites (Bilan et al., 2020; Bobenič Hintošová et al., 2018; Kostiukevych et al., 2020) In the first stage of such a research, the condition of a PPC, for instance, corporate staff, marketing system quality, economic performance, socioeconomic development of a country/region, etc., is assessed by means of applying multi-criteria assessment methods (Gedvilaitè, 2019; McLaren et al., 1998; Molly, 2018; Oželienė, 2019; Strezov et al., 2017; Volkov, 2018). In the second stage, correlation-regression analysis is invoked to find out what impact this condition had on different SES parameters, e.g., what impact the quality of corporate staff had on corporate economic performance.

The main purpose of quantitative assessment of a SES's condition is its improvement through purposeful management. It is generally accepted that improvements can only be made if a SES's condition can be assessed at a target point in time. To address this type of problem, a variety of multi-criteria assessment methods can be applied. Some of them (sum of ranks, geometric mean, Simple Additive Weighting (SAW), etc.) are simpler (Hwang \& Yoon, 1981; Ginevičius \& Podvezko, 2007; Zavadskas \& Kaklauskas, 1996), while others, such as AHP, TOPSIS, VICOR, PROMETEI, MOORA, ELEKTRE, UTA, ORESTE, LINMAP, etc., are more complicated (Atta Mills et al., 2020; Benayoun et al., 1966; Brans et al., 1984; Brans et al., 1986; Brauers \& Zavadskas, 2006; Hwang \& Yoon, 1981; Jacquet-Lagreze \& Siskos, 1982; Opricovic, 1998; Opricovic \& Tzeng, 2004; Roubens, 1982; Roy, 1988; Roy, 1996; Roy, 1991; Saaty, 1977; Saaty, 1980; Saaty et al., 2003; Srinivasan \& Shocker, 1973; Nazari-Shirkouhi et al., 2020; Turskis, 2008; Zahedi, 1986; Popp et al., 2019; Oláh et al., 2020).

On the other hand, the theory of multi-criteria assessment still contains many unresolved methodological issues, the essential one of which is an indicator system formation for a PPC. It covers the following aspects: selection of the indicators to be used in further calculations; formation of a system adjusted to multi-criteria assessment based on the indicators selected; assessment of a PPC's condition based on a hierarchically structured indicator system, etc.

Selection of the indicators for further calculations is necessary because their impact on a PPC is unequal. Thus, only sufficiently influential indicators must be selected.

Formation of an indicator system is impeded by the fact that depending on the nature of a PPC, the number of the indicators may vary from only a few to several tens. If the number of the indicators is large, then the system must be developed to suit multi-criteria assessment. In addition, it is necessary to project a calculation procedure based on the system developed.

\section{Formation of an adequate indicator system for a PPC}

As already mentioned, the process of multi-criteria assessment starts from selection of target indicators for further calculations. Target indicators can be selected in two ways. First of them is simpler. It is based on prevailing opinions, i.e. most commonly employed, universally recognised indicators are selected. Such selection is usually performed in a tabular form (Table 1).

Based on Table 1, the indicators most commonly mentioned by different authors are selected. Nevertheless, such method of forming an indicator system is inaccurate as it is difficult to define the threshold above which the indicators are included in the list, and below which the indicators are excluded from the list.

Mathematical statistics analysis methods are more accurate (Ginevičius \& Podvezko, 2004). 
Table 1. Formation of an indicator system based on prevailing opinions

\begin{tabular}{|c|c|c|c|c|c|c|c|}
\hline \multirow{2}{*}{ Author, source } & \multicolumn{7}{|c|}{ Names of indicators } \\
\hline & $1 \mathrm{st}$ & 2nd & 3rd & $\ldots$ & $i$ th & $\ldots$ & $n$th \\
\hline First & - & + & - & & + & & - \\
\hline Second & + & + & - & & - & & + \\
\hline Third & + & + & + & & + & & + \\
\hline$\vdots$ & $\vdots$ & $\vdots \vdots$ & $\vdots$ & & $\vdots$ & & $\vdots$ \\
\hline The $i$ th & - & + & + & $\ldots$ & + & $\ldots$ & - \\
\hline$\vdots$ & $\vdots$ & $\vdots$ & $\vdots$ & & $\vdots$ & & $\vdots$ \\
\hline The $k$ th & - & + & - & $\ldots$ & + & $\ldots$ & + \\
\hline Total & $\Sigma 1$ & $\Sigma 2$ & $\Sigma 3$ & $\cdots$ & $\Sigma i$ & $\ldots$ & $\sum_{i=1}^{n} n$ \\
\hline
\end{tabular}

Source: compiled by the author

With reference to Table 1, arrangement of the indicators according to the frequency of their mentioning reveals a particular regularity. The resulting histogram allows the selection of a theoretical probability distribution; it also allows estimating the theoretical frequencies of mentioning an indicator and calculating the percentage of the indicators which need to be excluded $(5,10$, etc.). Based on this, it can be identified how many indicators at the end of the histogram can be excluded from the indicator system (Figure 1).

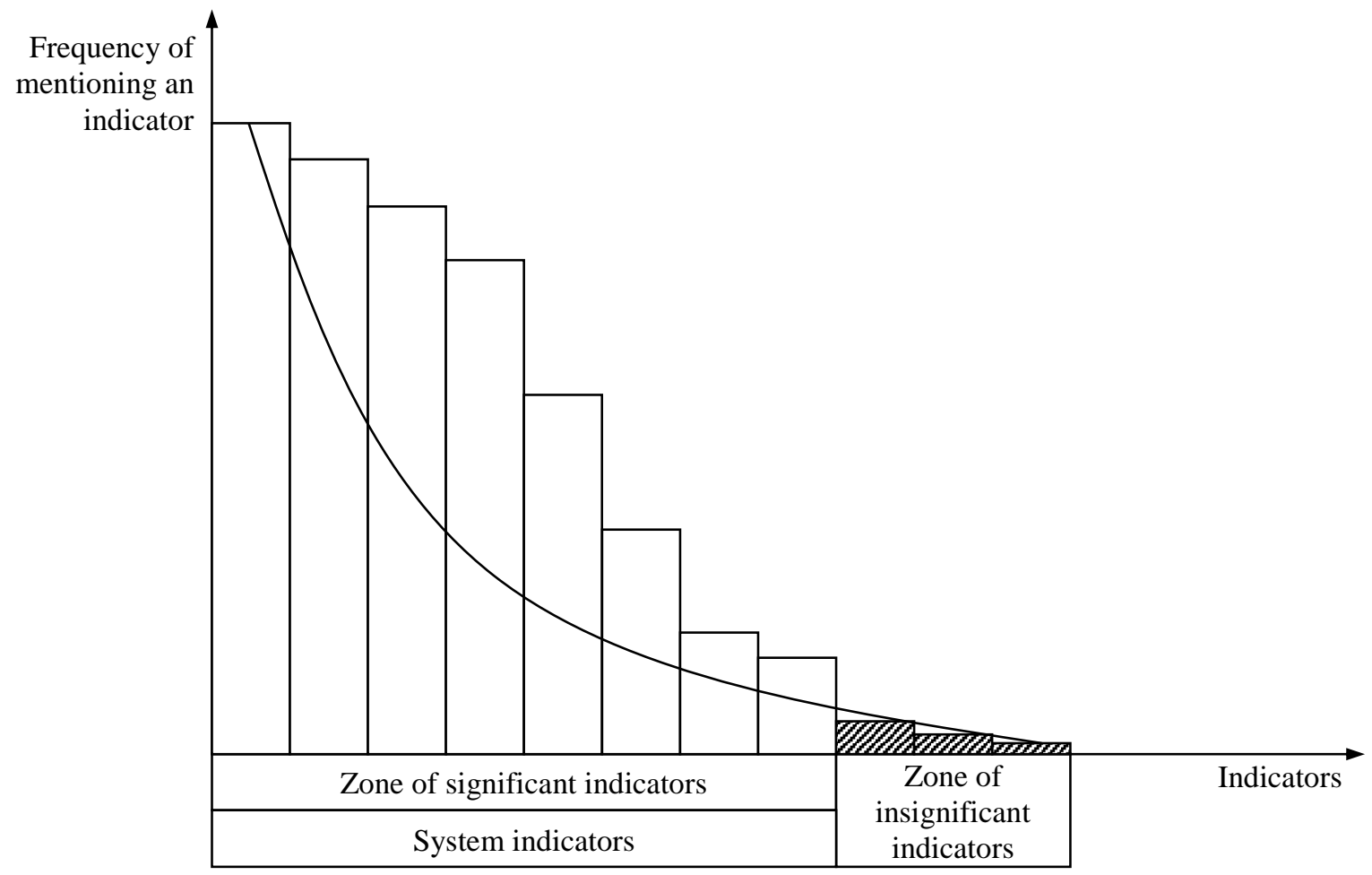

Figure 1. Formation of a PPC's indicator system based on mathematical statistics methods Source: compiled by the author with reference to Ginevičius \& Podvezko, 2004

Formation of an indicator system does not finish with selection of indicators because it is only their setup, which satisfies one of the conditions of systems theory - it is condition of entirety. In other words, this setup adequately reflects a PPC.

Another condition that is imposed on a system (a setup of particular indicators representing a PPC is treated as a system) is the structuring condition. It is based on the fact 
that all PPC's indicators, as elements of a system, are interrelated. Systems theory proposes that interrelations of the system elements have to be directed to achieve a common purpose of the whole system, i.e. they have to be purposeful (Ginevičius, 2009). Purposefulness of the setup turns the combination of related indicators (i.e. the indicators that reflect the same aspect of a PPC, ) into a single integrating quantity (index). The set of such indicators forms a higher hierarchical level of an indicator system. If the total number of indicators is large, then there may be more such indicators. By analogically combining related indicators, another, third, hierarchical level is obtained. The process is continued to a desired degree of aggregation. The final result is the quantity that reflects the condition of the entire PPC. It is obtained by aggregating top-level indicators.

If the number of indicators reflecting a PPC is small, the need to form a hierarchically structured indicator system disappears because the condition of a PPC can be assessed on the basis of a one-level indicator system (Figure 2).

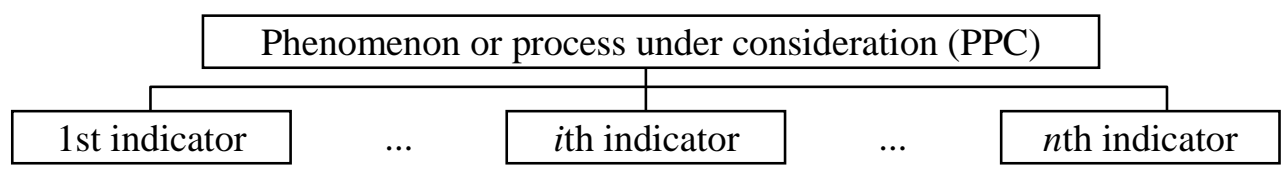

Figure 2. Reflection of a PPC in a one-level indicator system

Source: compiled by the author

In order for multi-criteria assessment methods to be used to quantitatively assess the condition of a PPC, an indicator system formed must be subject to certain restrictions.

When performing multi-criteria assessment, each indicator is expressed in two quantities - value and significance, or weight. The latter is provided by experts. The essence of expert evaluations is that in order to "weigh" the significance of an indicator, an expert must also evaluate the significance of all other indicators, i.e. to evaluate the significance of all indicators in relation to significance of an individual indicator. If the number of the indicators to be assessed is small, an expert can evaluate this relation quite accurately, but when the number of the indicators is rising, the situation is completely changing. It is becoming increasingly difficult for an expert to feel the relation to be assessed, thus the accuracy of evaluation is decreasing. It is logical to assume that there exists a limit to when an expert's capacity, regardless of his or her competence, starts coming to an end. Literature sources propose that this limit is equal to 12-13 indicators (Saaty, 1980; Šaparauskas, 2004; Volkov, 2018).

The above-mentioned limitation essentially concerns the lowest level of a hierarchically structured indicator system that groups all the indicators reflecting a PPC. Thus, all of the indicators must be grouped in such a way that none of the groups contains more than 12-13 indicators.

There are two ways of forming a hierarchically structured indicator system: "top-down" and "bottom-up" (Ginevičius, 2009). The first way is meaningful when most essential aspects of a PPC can be easily identified. The second way is meaningful when the aspects of a PPC are not prominent, and only a set of indicators describing a PPC is possessed.

"Top-down" forming a hierarchically structured indicator system. Social development of a country's regions can serve as a typical example of forming a hierarchically structured indicator system by this method. Alongside economic and ecological development, social development is distinguished as most complex by the theory of sustainable development of socio-economic systems (Gedvilaite, 2019). This is also evidenced by a number of social development indicators presented in various statistical issues. In our case, the number of the indicators is equal to 17 (Vansevičius \& Tyla, n.d.). 
In this case, "top-down" forming a hierarchically structured indicator system is meaningful because various aspects of regional social development, e.g. population, social protection, education, etc., can be distinguished very clearly. Quantitatively assessed aspects mentioned above will turn into the indicators of the highest hierarchical level. Finally, all 17 indicators are assigned to the relative aspects. This way, the groups of related indicators will form the lowest level of the hierarchical structure. After doing so, a system of hierarchically structured indicators representing regional social development is obtained (Figure 3) (Ginevičius, 2009; Gedvilaite, 2019; Ginevicius, 2019).

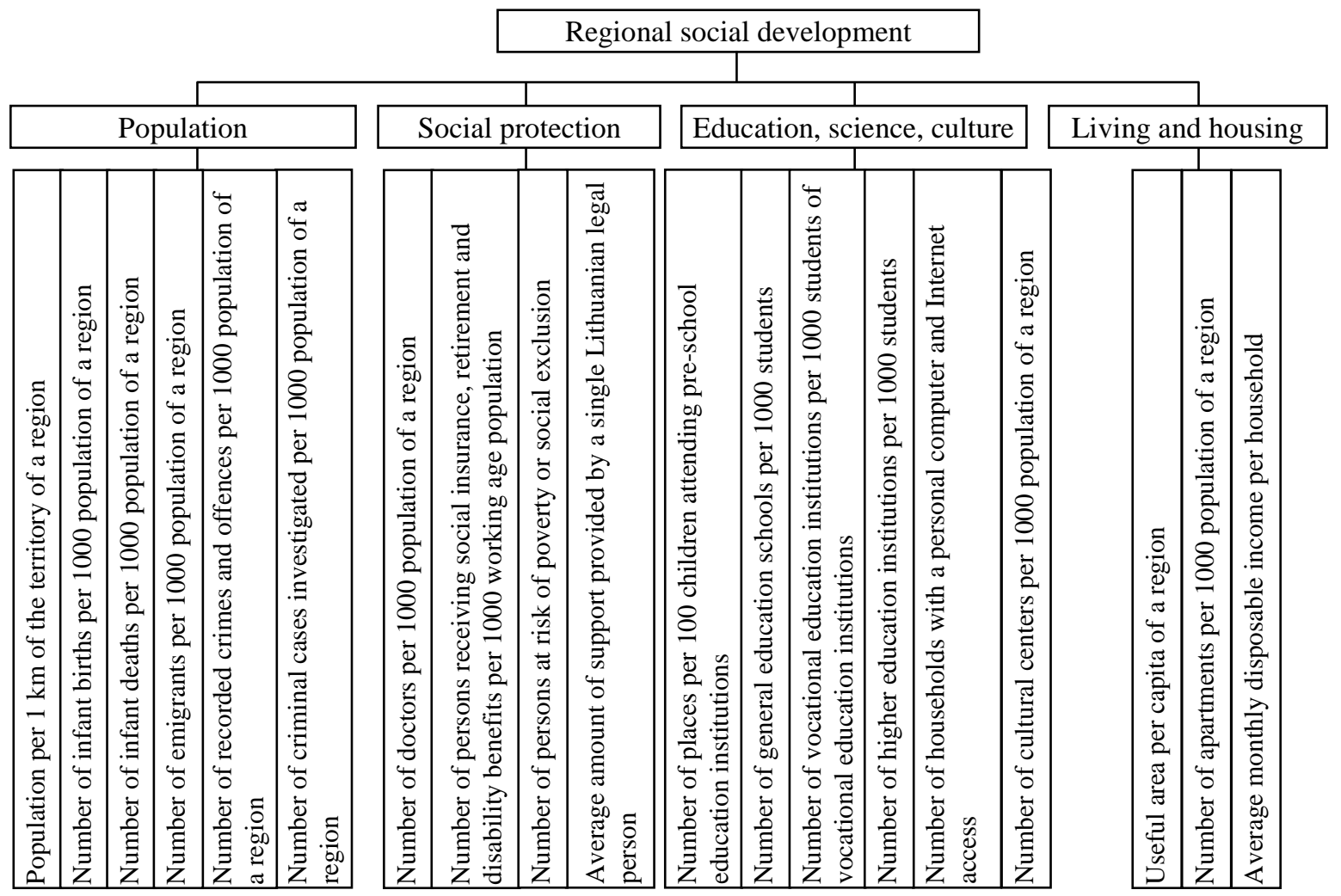

Figure 3. A system of hierarchically structured indicators representing regional social development

Source: Ginevičius, 2009; Gedvilaitè, 2019

"Bottom-up" forming a hierarchically structured indicator system. Identification of corporate strategic potential can serve as a typical example of forming a hierarchically structured indicator system by this method (Ginevičius \& Podvezko, 2004). It can be expressed by 14 indicators that do not unequivocally reflect particular aspects of corporate strategic potential (Table 2) (Ginevičius, 2009).

A deeper analysis of the core of the indicators presented in Table 2 shows that corporate strategic potential depends on two essential aspects: first, the capability of analysing, assessing and considering a set of external conditions; second, the capability of analysing, assessing and considering internal opportunities to meet external requirements. This way, the internal and external conditions of corporate strategic potential are the lowest level elements in the hierarchical structure. By combining the aspects reflecting both internal and external business conditions into related groups, the indicators of a higher hierarchical level are obtained.

Following the above-mentioned principles, the system of corporate strategic planning indicators will look as depicted in Figure 4. 
Table 2. Indicators of corporate strategic potential

\begin{tabular}{cl}
\hline No. & Indicator title \\
\hline 1 & Capability of analysing domestic and foreign macroeconomic situation \\
\hline 2 & Capability of timely identifying major customer requirements, needs and potential orders \\
\hline 3 & $\begin{array}{l}\text { Capability of analysing the requirements of products (services) that allow to meet new needs of } \\
\text { potential customers in a timely and high-quality manner }\end{array}$ \\
\hline 4 & Capability of analysing market success factors and rival activities in the market \\
\hline 5 & $\begin{array}{l}\text { Capability of generating new competitive ideas in the area of organising production (supply) of the } \\
\text { products (services) in demand }\end{array}$ \\
\hline 6 & $\begin{array}{l}\text { Capability of implementing new competitive ideas in the area of organising production (supply) of the } \\
\text { products (services) in demand }\end{array}$ \\
\hline 7 & Capability of ensuring the development and flexibility of a company's production system \\
\hline 8 & Capability of maintaining a company's competitiveness \\
\hline 9 & $\begin{array}{l}\text { Capability of ensuring a company's internal flexibility by providing the production process with } \\
\text { adaptive technological and other measures }\end{array}$ \\
\hline 10 & $\begin{array}{l}\text { Capability of ensuring internal flexibility of the production system by forming an adequate potential of } \\
\text { human resources in accordance with changing objectives }\end{array}$ \\
\hline 11 & $\begin{array}{l}\text { Capability of ensuring competitiveness of products (services) to lead the way in current and promising } \\
\text { markets }\end{array}$ \\
\hline 12 & $\begin{array}{l}\text { Capability of producing and providing products (services) to the extent that corresponds to a } \\
\text { company's competitive capacities and a desired market share }\end{array}$ \\
\hline 13 & $\begin{array}{l}\text { Capability of ensuring a company's effective functioning by rationally exploiting investment } \\
\text { opportunities }\end{array}$ \\
\hline 14 & $\begin{array}{l}\text { Capability of effectively forming and implementing the strategic program for a company's technical } \\
\text { and social development }\end{array}$ \\
\hline
\end{tabular}

Source: Ginevičius \& Podvezko, 2004

\begin{tabular}{|c|c|c|c|c|c|c|c|c|c|c|c|c|c|}
\hline & & & & & & & & & & & & & \\
\hline & & & & & & & & & & & & & \\
\hline & & Exter & $\mathrm{cc}$ & & & & & & & terr & ondit & & \\
\hline & & & & & & & & & & & & & \\
\hline & & & & & $\bar{n}$ & & & & & & & & \\
\hline .0్ㅗ & $\tilde{z}$ & $\stackrel{\varrho}{\stackrel{\Xi}{\sigma}} \geqq$ & $\stackrel{\mathscr{g}}{\Xi}$ & $:$ & 苛 & $\stackrel{n}{3}$ & & & $\equiv$ & & $\overrightarrow{\bar{\theta}} z$ & & \\
\hline : & $\stackrel{\Xi}{=}$ & 苂 & $\stackrel{\mathscr{0}}{=}$ & $\begin{array}{l}\bar{\sigma} \\
\bar{\sigma} \\
\bar{\sigma}\end{array}$ & $\frac{0}{0}$ & 言 & & 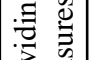 & 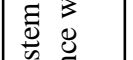 & & 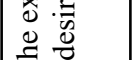 & & $\frac{\vec{c}}{60}$ \\
\hline$E$ & : & 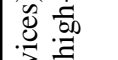 & 氞 & & 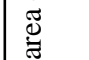 & $\mid \begin{array}{l}0 \\
0 \\
\sigma\end{array}$ & & 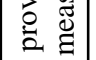 & 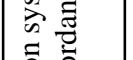 & & 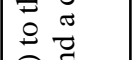 & & \\
\hline हैं & 롤 & 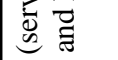 & $\frac{\pi}{\pi}$ & $\stackrel{\Xi}{\Xi}$ & $\stackrel{\oplus}{\Xi} \bar{\Xi}$ & $\mid \begin{array}{l}4 \\
0 \\
\lambda\end{array}$ & $b_{0}$ & 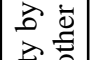 & 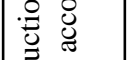 & & 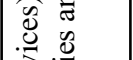 & & $\bar{F}$ \\
\hline $\mathbb{Z}$ & ఫ్ర్ర & $\stackrel{n}{0} \frac{\lambda}{d}$ & $\Xi$ & 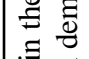 & $\begin{array}{l}. \Xi \bar{\Xi} \\
\tilde{g}\end{array}$ & : & $\stackrel{\Xi}{\Xi}$ & $\mid \begin{array}{ll}0 \\
:\end{array}$ & $\begin{array}{l}\overline{0} \\
0.5 \\
0\end{array}$ & & 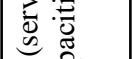 & & $=$ \\
\hline & $\bar{\Xi}$ & 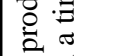 & $\begin{array}{l}\sigma \\
0 \\
0 \\
\vdots\end{array}$ & $\Xi$ & $: \frac{\pi}{2} . \Xi$ & $\frac{x}{\underline{e}}$ & 苛 & 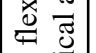 & छ & & 范 & & \\
\hline 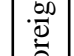 & $\stackrel{0}{0}$ & $\begin{array}{c}4 \\
0 . \Xi \\
0\end{array}$ & 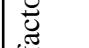 & $\frac{0}{0}$ & 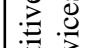 & $\bar{\Xi}$ & $\Xi$ & $\bar{\sigma} \bar{g}$ & $\mid \begin{array}{ll}4 & 0 \\
0 & 0 \\
\lambda & 0\end{array}$ & & t) & & \\
\hline 0 & : & 坣 & 离 & 离 & 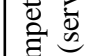 & $\overrightarrow{\underline{0}}$ & $\begin{array}{l}n \\
2\end{array}$ & 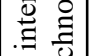 & 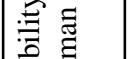 & $\begin{array}{ll}0 \\
0 \\
0 & \infty\end{array}$ & 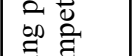 & & \\
\hline & 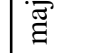 & 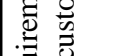 & 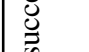 & قै & 0 & ةै & డ్ & $\left.\mid \begin{array}{ll}n & 0 \\
\geq & 0 \\
0\end{array}\right]$ & 苑刍 & & : & $n s$ & \\
\hline$\underset{\approx}{\mathscr{E}}$ & $\stackrel{\infty}{\equiv}$ & 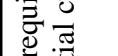 & $\vec{v}$ & 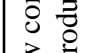 & 存 & $\stackrel{0}{2}$ & हี & 㺃: & $\frac{5}{\pi}$ & : & 总. & $\approx$ & \\
\hline 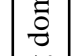 & 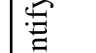 & 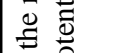 & 鸮 & 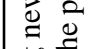 & .00 & 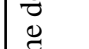 & $\begin{array}{l}\infty \\
0 \\
0 \\
0\end{array}$ & E & E & & & J & $4 \pi$ \\
\hline$\stackrel{5}{:}$ & 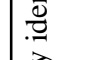 & 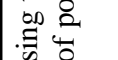 & .0 & 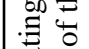 & 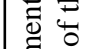 & $\begin{array}{l}7 \\
000 \\
=\end{array}$ & 吕 & $\mid \begin{array}{ll}\pi \\
0.0\end{array}$ & $\mid \begin{array}{ll}0.0 \\
00\end{array}$ & $\mid$ & & 我 & 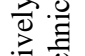 \\
\hline สี & $\widehat{\overrightarrow{0}}$ & 㐘 & 文 & $\frac{\pi}{0}$ & 흘 $\frac{\widehat{a}}{2}$ & 跣 & 节 & $\left.\mid \begin{array}{ll}\bar{E} & 0 \\
0 & 0 \\
g & 0 \\
0\end{array}\right]$ & 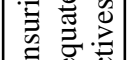 & 言 & & 19 & $=\infty$ \\
\hline tै। & 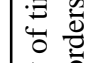 & 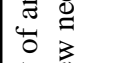 & & 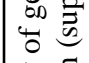 & 兒言 & $\begin{array}{l}\overline{0} \\
\overline{0}\end{array}$ & $\underbrace{E}_{0}$ & 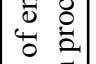 & 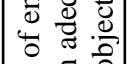 & 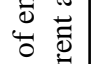 & $\begin{array}{l}\vec{z} \\
\overrightarrow{0} \\
\overrightarrow{0}\end{array}$ & $\left.\mid \begin{array}{ll}\bar{E} & 0 \\
& 0\end{array}\right]$ & 0 \\
\hline$\stackrel{2}{:}$ & : & 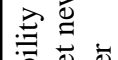 & $\stackrel{\gtrless}{:}$ & ㄹ. & 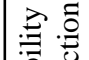 & 己. & $\stackrel{2}{=}$ & : & 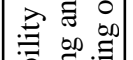 & $\stackrel{3}{3}$ & 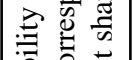 & 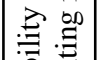 & : \\
\hline 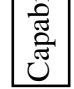 & 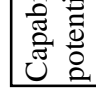 & 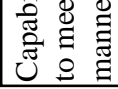 & 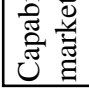 & 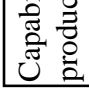 & 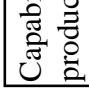 & 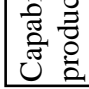 & 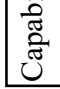 & 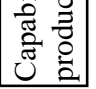 & 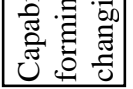 & 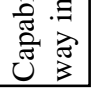 & 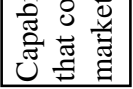 & 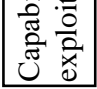 & 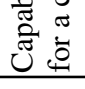 \\
\hline
\end{tabular}

Figure 4. A hierarchically structured system of corporate strategic potential indicators Source: Ginevičius \& Podvezko, 2004 
As it can be seen from Figures 3 and 4, the indicator systems in both cases are adapted to multi-criteria assessment as the number of the indicators simultaneously evaluated by experts does not exceed 12-13 indicators.

The advantage of a hierarchically structured indicator system over a single-level indicator system is that a PPC can be represented by a substantially larger number of indicators without compromising the accuracy of its quantification.

Multi-criteria assessment of a socio-economic system based on a hierarchically structured indicator system starts from the bottom. In particular, the values of individual aspects of the structure need to be estimated, which is accomplished in the following way (Hwang \& Yoon, 1981):

$$
K_{j}=\sum_{i=1}^{n} \omega_{i j} \tilde{q}_{i j}
$$

here $K_{j}$ - the value of multi-criteria assessment of the $j$ th aspect of regional social development by the SAW method; $\omega_{i j}$ - significance of the $i$ th indicator of the $j$ th aspect; $\tilde{q}_{i j}$ - normalised value of the $i$ th indicator of the $j$ th aspect.

Table 3 below provides the values of multi-criteria assessment of various aspects representing regional social development.

Table 3. The values of multi-criteria assessment of different aspects representing regional social development in Lithuania

\begin{tabular}{ccccc}
\hline \multirow{2}{*}{ Year } & \multicolumn{4}{c}{ Social development aspects } \\
\cline { 2 - 5 } & population & social protection & education, science, culture & living conditions \\
\hline 2019 & 0.18401257 & 0.21724043 & 0.10178377 & 0.23941606 \\
\hline 2018 & 0.18107463 & 0.20943895 & 0.10447555 & 0.20703097 \\
\hline 2017 & 0.19843528 & 0.21063701 & 0.1032107 & 0.17594237 \\
\hline 2016 & 0.1914705 & 0.20037235 & 0.10229144 & 0.15831594 \\
\hline 2015 & 0.19029613 & 0.1906721 & 0.10192508 & 0.14667329 \\
\hline
\end{tabular}

Source: Gedvilaite, 2019

By combining the values representing different aspects of regional social development (Table 3) into a single integrating quantity, the generalised value representing regional social development will be obtained. Estimations are performed in an analogous way, i.e. by summing the products of aspect significance and value:

$$
K_{s}=\sum_{j=1}^{m} \omega_{j} \cdot K_{j}
$$

here $K_{s}$ - the value of regional social development; $\omega_{j}$ - significance of the $j$ th development aspect.

Based on the data in Table 3 and the weights of different aspects provided by experts, the following values of the index representing regional social development are obtained (Table 4):

Table 4. The values of multi-criteria assessment representing regional social development

\begin{tabular}{lrrrrr} 
Year & 2015 & 2016 & 2017 & 2018 & 2019 \\
\hline
\end{tabular}

\begin{tabular}{llllll}
\hline The value of multi-criteria assessment & 0.70202009 & 0.74245283 & 0.751336253 & 0.75825139 & 0.77215873 \\
\hline
\end{tabular}

Source: Gedvilaité, 2019 
The values estimated for all regions of a country can be ranked by the degree of regional social development. The results obtained can be employed to improve regional development policies aimed at reduction of development gaps between individual regions.

\section{Conclusions}

Forming an adequate indicator system for a PPC is one of the key issues determining the accuracy of multi-criteria assessment. It is especially relevant when a PPC is reflected by a large number of indicators. Of all the options of quantifying the condition of a SES, the methods of multi-criteria assessment can be treated as most reliable. On the other hand, an indicator system must be developed to meet the requirements of the indicators, i.e. it must be considered that in the multi-criteria assessment process, each indicator is expressed by two quantities significance and value. An adequate evaluation of indicator significance is limited by the number of indicators because experts can provide sufficiently accurate evaluations only for a limited number of indicators. It is considered that this number is equal to 10-12. Forming a hierarchically structured indicator system provides the solution to this problem. In this case, based on the number of indicators, the indicators at the lowest level of the hierarchical structure are grouped according to their representation of a particular aspect in a higher level of the hierarchical structure. If the number of such aspects and representative indicators is large, an even higher level of the hierarchical structure of formed, and so forth.

A hierarchically structured indicator system can be formed in two ways - "top-down" and "bottom-up". The first way is meaningful when most essential aspects of a PPC can be easily identified, while the second way is meaningful when the aspects of a PPC are not prominent, and only a set of indicators describing a PPC is possessed.

Multi-criteria assessment of a hierarchically structured indicator system starts from the bottom - the values of the indicator groups are estimated, which, multiplied by significance of an aspect, turn into an index. By combining these indices into a single integrating quantity, the final value representing the condition of a SES is obtained.

Such a procedure for quantitative assessment of the condition of complex phenomena or processes can be employed for solving a wide range of problems, e.g. selecting the best building design, ranking a country's regions by the level of their socio-economic development for improvement of regional policies, assessing the quality of staff, marketing system, etc.

\section{References}

Atta Mills, E. F. E., Baafi, M. A., Amowine, N., \& Zeng, K. (2020). A hybrid grey MCDM approach for asset allocation: evidence from China's Shanghai Stock Exchange. Journal of Business Economics and Management, 21(2), 446-472. Retrieved from https://doi.org/10.3846/jbem.2020.11967

Babu, S., \& Datta, S. (2015). Revisiting the link between socio-economic development and environmental status indicators focus on panel data. Environment Development and Sustainability, 17(3), 567-586. doi:10.1007/s10668-014-9561-6

Benayoun, R., Roy, B., \& Sussman, B. (1966). Electre: Une méthode pour guider le choix en présence de points de vue multiples. Note de travail, 49, SEMA-METRA International Direction Scientifique.

Bilan Y., Mishchuk, H., Roshchyk, I. \& Kmecova I. (2020). Analysis of Intellectual Potential and its Impact on the Social and Economic Development of European Countries. Journal of Competitiveness, 1, 22-38. https://doi.org/10.7441/joc.2020.01.02 
Bilan, Y., Vasilyeva, T., Lyeonov, S., \& Bagmet, K. (2019). Institutional complementarity for social and economic development. Business: Theory and Practice, 20, 103-115. Retrieved from https://doi.org/10.3846/btp.2019.10

Bobenič Hintošová, A., Bruothová, M., Kubíková, Z., \& Ručinský R. (2018). Determinants of foreign direct investment inflows: A case of the Visegrad countries. Journal of International Studies, 11(2), 222-235. doi:10.14254/2071- 8330.2018/11-2/15

Boggia, A., Rocchi, L., Paolotti, L., Musotti, F., \& Greco, S. (2014). Assessing rural sustainable development potentialities using a dominance-based rough set approach. Journal of Environmental Management, 144, 160-167.

Brans, J. P., Mareschal, B., \& Vincke, Ph. (1984). PROMETHEE: A new family of outranking methods in multicriteria analysis. In Operational Research' 84. (J. P. Brans, Ed.) North Holland: Elsever Science Publishers B. V.

Brans, J. P., Vincke, Ph., \& Mareschal, B. (1986). How to select and how to rank projects: The Promethee method. European Journal of Operational Research, 24(2), 228-238. Retrieved from https://doi.org/10.1016/0377-2217(86)90044-5

Brauers, W. K. M., \& Zavadskas, E. K. (2006). The MOORA method and its application to privatization in a transition economy. Control and Cybernetics, 35(2), 443-468.

Chowolhury, S., \& Squire, L. (2006). Setting weights for aggregate indices: an application to the commitment to development index and human development index. Journal of Development Studies, 42(5), 761-771.

Gedvilaite, D. (2019). The assessment of sustainable development of a country's regions. Doctoral dissertation. Vilnius: Technika.

Ginevicius, R. (2019). Quantitative Assessment of the Compatibility of the Development of Socioeconomic Systems. Journal of Competitiveness, 11(2), 36-50. https://doi.org/10.7441/joc.2019.02.03

Ginevičius, R. (2009). Some problems of quantitative evaluation of the state of social-economic systems. Business: Theory and Practice, 10(2), 69-83.

Ginevičius, R., \& Podvezko, V. (2004). Imonių strateginio potencialo kiekybinis vertinimas. (Quantitative Evaluation of the Strategic Potential of Enterprises). Verslas: teorija ir praktika - Business: Theory and Practice, V(1), 3-9.

Ginevičius, R., \& Podvezko, V. (2007). Some problems of evaluating multicriteria decision methods. International Journal of Management and Decision Making, 8(5/6), 527-539.

Hwang, C. L., \& Yoon, K. (1981). Multiple Attribute Decision Making. Methods and Application a State-of-the-Art Survey. Lecture Notes in Economics and Mathematical Systems 186. Berlin, Heidelberg: Springer.

Jacquet-Lagreze, E., \& Siskos, J. (1982). Assessing a set of additive utility functions for multicriteria decision-making, the UTA method. European Journal of Operational Research, 10(2), 151-164. Retrieved from https://doi.org/10.1016/0377-2217(82)901552

Kostiukevych, R., Mishchuk, H., Zhidebekkyzy, A., Nakonieczny, J., \& Akimov, O. (2020). The impact of European integration processes on the investment potential and institutional maturity of rural communities. Economics and Sociology, 13(3), 46-63. doi:10.14254/2071-789X.2020/13-3/3

McLaren, D., Bullock, S., \& Yousef, N. (1998). Tomorrow's world: Britain's share in a sustainable future. London.

Molly, K. M. (2018). Regional differences in Slovenia from the viewpoint of achieving Europe's sustainable development. Acta Geographica Slovenia, 58(2), 2-46.

Nazari-Shirkouhi, S., Mousakhani, S., Tavakoli, M., Dalvand, M. R., Šaparauskas, J., \& Antuchevičienè, J. (2020). Importance-performance analysis based balanced scorecard for performance evaluation in higher education institutions: an integrated fuzzy approach. 
Journal of Business Economics and Management, 21(3), 647-678. Retrieved from https://doi.org/10.3846/jbem.2020.11940

Oláh, J., Krisán, E., Kiss, A., Lakner, Z., \& Popp, J. (2020). PRISMA Statement for Reporting Literature Searches in Systematic Reviews of the Bioethanol Sector. Energies, 13(9), 2323, 1-34., https://doi.org/10.3390/en13092323

Opricovic, S. (1998). Multicriteria Optimization of Civil Engineering Systems. Belgrade, Serbia: Faculty of Civil Engineering.

Opricovic, S., \& Tzeng, G.-H. (2004). Compromise solution by MCDM methods: A comparative analysis of VIKOR and TOPSIS. European Journal of Operational Research, 156(2), 445-455. Retrieved from https://doi.org/10.1016/S03772217(03)00020-1

Oželienė, D. (2019). Modelling the factors of a company's sustainable development. Doctoral dissertation. Vilnius: Technika.

Popp, J., Békefi, E., Duleba, S., \& Oláh, J. (2019). Multifunctionality of pond fish farms in the opinion of the farm managers: the case of Hungary. Reviews in Aquaculture, 11(3), 830847. https://doi.org/10.1111/raq.12260

Roubens, M. (1982). Preference relations on actions and criteria in multicriteria decision making. European Journal of Operational Research, 10(1), 51-55. Retrieved from https://doi.org/10.1016/0377-2217(82)90131-X

Roy, B. (1988). Des critéresmultiples en recherche opérationnelle: Pourquoi? In G. K. Rand (ed.), Operational Research, 87. Amsterdam, North Holland.

Roy, B. (1991). The outranking approach and the foundations of ELECTRE methods. Theory and Decision, 31, 49-73. Retrieved from https://doi.org/10.1007/BF00134132

Roy, B. (1996). Multicriteria methodology for decision aiding. Dordrecht, Netherlands; Boston, Mass: Kluwer Academic Publishers.

Saaty, T. L. (1977). A scaling method for priorities in hierarchical structures. Journal of Mathematical Psychology, 15(3), 234-281. Retrieved from https://doi.org/10.1016/00222496(77)90033-5

Saaty, T. L. (1980). The Analytic Hierarchy Process. New York: McGraw-Hill.

Saaty, T. L., Vargas, L. G., \& Dellmann, K. (2003). The allocation of intangible resources: the analytic hierarchy process and linear programming. Socio-Economic Planning Sciences, $37(3), 169-184$.

Šaparauskas, J. (2004). Darnaus miesto vystymo(-si) daugiatikslè selektonovacija (Multiobjective selective innovation for sustainable urban development). Doctoral dissertation. Vilnius: Technika.

Srinivasan, V., \& Shocker, A. (1973). Linear programming techniques for multidimensional analysis of preferences. Psychometrika, 38(3), 337-369.

Strezov, V., Evens, A., \& Evans, T. J. (2017). Assessment of the economic, social and environmental dimensions of the indicators for sustainable development. Sustainable Development, 25(3), 242-253. Retrieved from https://doi.org/10.1002/sd.1649

Turskis, Z. (2008). Multi-attribute contractors ranking method by applying ordering of feasible alternatives of solutions in terms of preferability technique. Technological and Economic Development of Economy, 14(2), 224-239.

Vansevičius, S., \& Tyla, A. (n.d.). Lietuvos apskritys (Lithuanian regions). Retrieved from https://www.vle.lt/Straipsnis/Lietuvos-apskritys-125700

Volkov, A. (2018). Assessment of the impact of the common agricultural policy direct payments system on agricultural sustainability. Doctoral dissertation. Vilnius: Technika.

Zahedi, F. (1986). The Analytic Hierarchy Process: A Survey of the Method and Its Applications. Interfaces, 16(4), 96-108. Retrieved from https://www.jstor.org/stable/25060854 
Zavadskas, E. K., \& Kaklauskas, A. (1996). Pastatu sistemotechninis vertinimas (Systematictechnical evaluation of buildings). Vilnius: Technika. Retrieved from https://doi.org/10.1080/13921525.1998.10531385 